\title{
NORTHERN PHALAROPE FLOCKS AT MIQUELON LAKE, ALBERTA
}

\section{E. OTTO HÖHN, 11511 - 78 Avenue, Edmonton, Alberta, T6G ON4.}

Miquelon Lake, 28 miles southeast of Edmonton, is the largest, and northernmost of three lakes which are the remnants of a former single larger lake. Water levels in the original lake were greatly lowered by a temporary canal which was dug in 1927 to drain water into the reservoir of the town of Camrose, 15 miles south of the lake. This and a succession of dry years in the early thirties reduced Miquelon Lake to three separate bodies of water about its deepest portions.' More recently, a provincial campground has been set up along a segment of the lake shore. The sand brought in to convert its shoreline to a beach has made it attractive to shore birds, particularly during high water levels when the marginal stretches of mud along other portions of the shoreline are submerged. The lake lies in typical aspen parkland country and is surrounded by pastures and poplar woods.

I have visited this lake several times every summer for about 20 years, but although Northern Phalaropes are regular spring and fall migrants through the Edmonton district, I saw none of these birds there until early August 1969 when there was a flock of about 50 well offshore in the most western bay of the lake. During the late summer of the next 4 years, i.e., 1970-1973, flocks of Northern Phalaropes, at times with smaller numbers of Wilson's Phalaropes, were present for some weeks in the same part of the lake. Occasionally they were also seen further east off the beach of the provincial park where I had what may be the unique experience of swimming among phalaropes. While swimming, it was possible to come within about 6 feet of the birds. The estimated numbers of phalaropes of the two species named seen at Miquelon Lake during the 4 years of Northern Phalarope prevalence are shown in Table 1.

After 1973 , up to and including the summer of 1980 , the only flock of Northern Phalaropes noted at this lake was one of about 30 birds seen on 24 July 1976. These were in a part of the lake far from the area frequented during the 1970-1973 period.

To explain the limited period during which Northern Phalaropes occurred at Miquelon Lake in impressive numbers, I secured information about the level of the lake from the Alberta Department of Environment. Figure 1 shows the late July lake levels for the years 1964 to 1977 in relation to the estimated peak number of phalaropes seen there in July or August. It is evident that the phalarope years 1969-1973 were years when the water level of the lake was low compared to the preceding and following years. To put it another way, the lake attracted Northern Phalaropes in numbers when it was shallowest.

Northern and Red Phalaropes winter at sea, feeding on plankton organisms, and during this season they frequent deep water. However, during their occurrence inland, Northern Phalaropes prefer shallow to deep water. This is almost certainly a matter of diet. Wetmore found the 


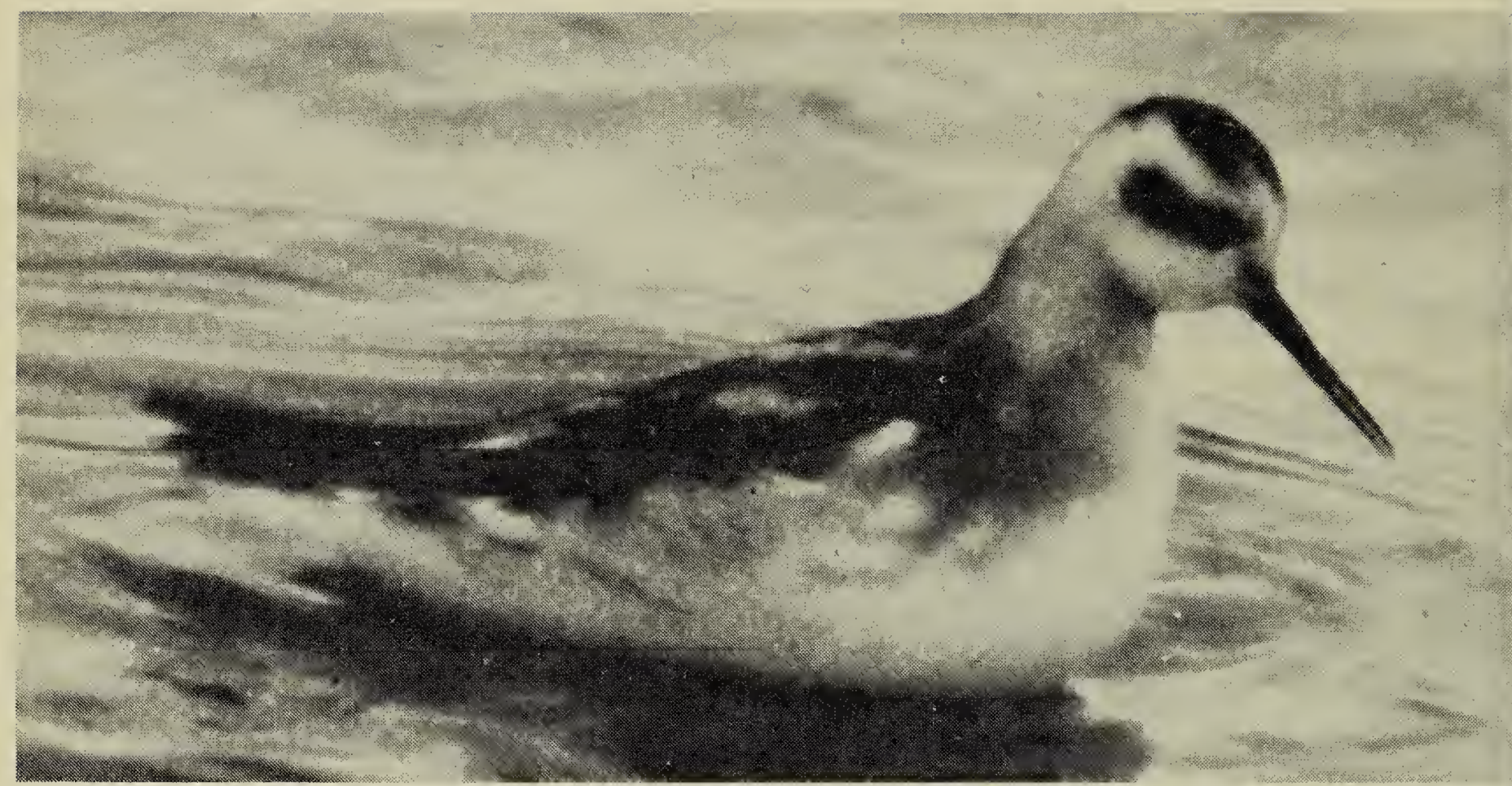

Northern Phalarope.

M. A. Gollop

main food items of Northern Phalaropes collected between May and October to be mosquito flies and larvae, aquatic hemiptera and aquatic beetles. ${ }^{3} \mathrm{Dr}$. G. Evans of the Department of Entomology, University of Alberta, told me that these are all inhabitants of the shallows but not the deeper portions of inland waters. This would explain why shallow rather than deep waters are attractive to these phalaropes.

But why do they not, when the lake water levels are higher, simply utilize

TABLE 1: Approximate numbers of phalaropes seen at Miquelon Lake, 1970-1972

Date

3 August 1970

8 August 1970

21 August 1970

22 August 1970

30 August 1970

18 July 1971

23 July 1971

29 July 1971

31 July 1971

7 August 1971

7 August 1972

12 \& 13 August 1972

16 August 1972

20 August 1972

3 September 1972

10 September 1972

1 October 1972

13 May 1973

4 August 1973

$20 \& 25$ August 1973
Northern

100

130

-

$\overline{-}$

hundreds

hundreds

200

$30+15$ on shore

1,000

hundreds

1,000

several hundreds

several hundreds 100

a few

1,000

1,000

1,000
Wilson's

some

16

100

20

30

some

2 on shore

10

$-$

-

$\overline{6}$

10 


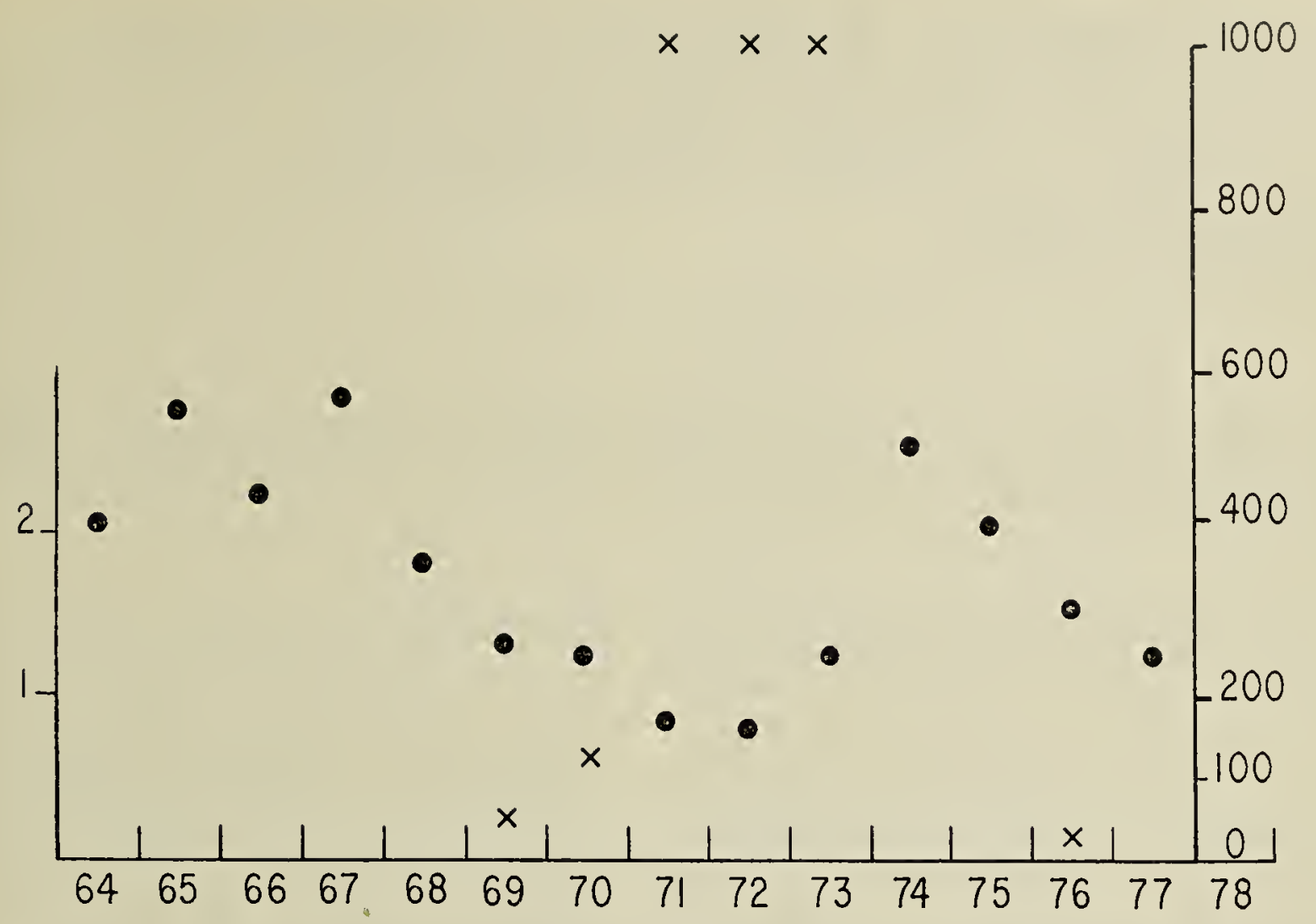

Figure 1. Left scale (dots): July water levels of Miquelon Lake above a standard elevation of 2,500 feet during the period 1964 to 1977 inclusive. Right scale (crosses): estimated peak numbers of Northern Phalaropes in July or August.

areas closer to the shore which should be shallow enough to suit them? While single Northern Phalaropes or small numbers of these birds are often seen just offshore or even on the shore, flocks of these birds at Miquelon Lake were always seen about 100 yards or more offshore. This also applies to the hundreds of Northern Phalaropes I saw on Manito Lake in western Saskatchewan on 16 and 17 August 1975. Beaverhill Lake lies some 20 miles from Miquelon Lake. I have only seen Northern Phalaropes there in small numbers but other observers who have seen large flocks there inform me that these keep well out from the shore. Salt and Salt also state that these phalaropes more often alight well out on the water than they run about on the shore. ${ }^{2}$ Given a strong preference of Northern Phalaropes when in flocks, for offshore waters which must, however, be shallow enough to suit the invertebrates on which they feed, the occurrence of flocks of these birds at Miquelon Lake in years of low water levels but not at other times becomes explicable. The preference of these birds for offshore rather than inshore waters may have some as yet unknown ecological basis. However, I suspect it may be a mere psychological trait which is more pronounced in this species than in Wilson's Phalaropes.

If these phalarope flocks have a strong preference to remain a certain distance from the vegetated or "permanent" shoreline of lakes, waters that are sufficiently far out may well be shallow enough for their food requirements only when lake levels are low.

'NYLAND, E. 1970. Miquelon Lake, Alberta. Lands Forests Parks Wildlife 13:18-25.

2SALT, W. R. and SALT, J. R. 1976. The birds of Alberta.

${ }^{3}$ WETMORE, cited from BENT, A. C. 1927. Life histories of North American shore birds. U.S. Natl. Museum Bull. 142, Washington. 